\title{
Pembuatan Produk Permen Agar-agar Buah
}

\section{Mamik Ponco Rahayu | Nuraini Harmastuti | Endang Sri Rejeki | Taufik Turahman*}

\author{
Fakultas Framasi, Universitas Setia Budi Surakarta \\ Jl. Ir. Let. Jend. Sutoyo Mojosongo, Solo 57127
}

\begin{abstract}
Abstrak
Warga masyarakat Ngampon di Kelurahan Mojosongo, Jebres, kota Surakarta menghadapi masalah mata pencaharian yang beragam yang sebagian besar adalah buruh pabrik dengan tingkat penghasilan yang rendah dan peran ibu-ibu hanya sebagai ibu rumah tangga. Maka perlu adanya kegiatan pelatihan pembuatan produk permen agar-agar buah sebagai alternatif home industri rumahan untuk penambah pendapatan keluarga. Kegiatan pengabdian kepada masyarakat ini dirancang dengan melakukan pelatihan pembuatan produk permen agar-agar buah. Target dari kegiatan di atas adalah masyarakat akan mendapat tambahan ketrampilan membuat peroduk permen agar-agar buah yang dapat dilakukan dengan mudah dan modal kecil sehingga dapat sebagai salah satu alternatif home industri keluarga.
\end{abstract}

Kata Kunci: Buah, permen agar-agar, home industri

\section{Pendahuluan}

Warga masyarakat Ngampon di Kelurahan Mojosongo, Jebres, Surakarta merupakan perkampungan padat, berlokasi sekitar $500 \mathrm{~m}$ dari kampus USB. Masyarakat di daerah ini mempunyai mata pencaharian yang beragam, sebagian besar adalah wiraswasta dan sebagian buruh pabrik dengan tingkat penghasilan yang rendah. Tingkat kepadatan penduduk cukup tinggi, dihuni sekitar 100 kepala keluarga. Maka warga sangat menantikan transfer ilmu dari Universitas Setia Budi dalam bentuk pengabdian kepada masyarakat terkait dengan peningkatan ketrampilan dan motivasi perintisan home indutri dalam upaya peningkatan perekonomian warga.

Dapat dirumuskan beberapa masalah yang dihadapi warga masyarakat Ngampon di Kelurahan Mojosongo, Jebres, Surakarta bahwa Masyarakat masih perlu adanya pelatihan untuk meningkatkan ketrampilan dan motivasi dalam menciptakan peluang usaha rumahan (home industri) dengan produkproduk yang dapat dilakukan dengan mudah yang sekaligus menambah income penduduk. Tujuan dari kegiatan ini adalah, 1) Melaksanakan Tri Dharma Perguruan Tinggi, 2) Meningkatnya motivasi perintisan home indutri dalam upaya peningkatan perekonomian warga, 3) Meningkatkan ketrampilan ibu-ibu PKK kelurahan Mojosongo melalui pelatihan pembuatan produk permen agar-agar buah.

\section{Metode Pelaksanaan}

Pengabdian masyarakat dalam bentuk penyuluhan dan pelatihan pembuatan produk permen agar-agar buah kepada ibu-ibu PKK Ngampon di Kelurahan Mojosongo Kecamatan Jebres Kota Surakarta. Perijinan ke Kelurahan Mojosongo, Jebres, Kota Surakarta dilanjukan dengan memberikan penyuluhan dan pelatihan pembuatan produk permen agar-agar buah. Pengabdian diakhiri dengan evaluasi dan follow up hasil produk yang dibuat oleh masyarakat setempat. Bahan dan alat yang digunakan dalam kegiatan pengabdian ini adalah: buah naga, gula pasir 1 gelas kecil peres, air $200 \mathrm{ml}$, agar-agar, daun mint secukupnya, kompor oven, blender, panci stainless steel, pengaduk kayu, baskom, pisau, talenen, baki plastik/loyang, timbangan, saringan/kain saring, sendok makan.

*Email korespondensi: Taufikturahman@gmail.com 


\section{Hasil dan Pembahasan}

Program pengabdian masyarakat ini dihadiri oleh 15 peserta yang terdiri dari para ibu-ibu PKK Ngampon di kelurahan Mojosongo Kecamatan Jebres Kota Surakarta. Program pelatihan menggunakan sarana multi media berupa video, white board, kompor, dan gas, panci dan seperangkat alat untuk membuat produk permen agar-agar buah (Gambar 1).

Materi pelatihan dalam bentuk hardcopy selain itu pelatihan pembuatan produk permen agar-agar buah sesuai Gambar 1, yang dilanjutkan dengan follow up melalui program pendampingan selama satu bulan. Kegiatan pengabdian diselenggarakan pada hari Jumat tanggal 8 Agustus 2018 dengan bentuk penyuluhan dan pelatihan pembuatan produk permen agar-agar buah. Pada pelaksanaan kegiatan penyuluhan dan pelatihan pembuatan produk permen agar-agar buah, peserta memperhatikan dan berperan aktif dalam kegiatan penyuluhan dan pelatihan, dan dalam tanya jawab terbuka para peserta berantusias bertanya. Target Luaran dalam kegiatan pengabdian ini adalah berupa produk permen agaragar buah.
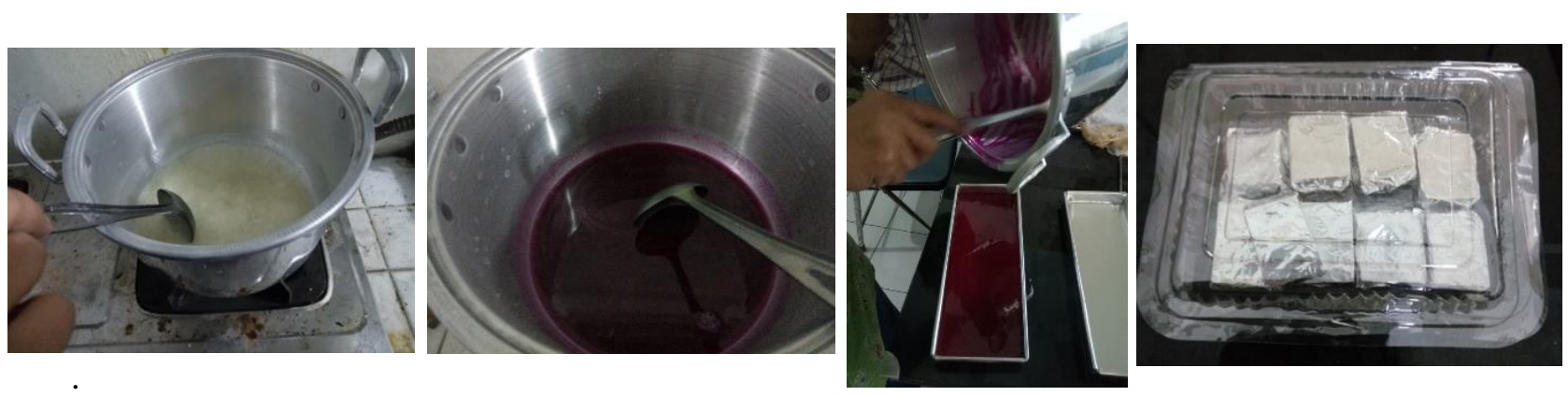

Gambar 1. Proses pembuatan permen agar-agar buah.

\section{Kesimpulan}

Kegiatan pengabdian masyarakat dalam bentuk penyuluhan dan pelatihan pembuatan produk permen agar-agar buah kepada ibu-ibu PKK Ngampon di kelurahan Mojosongo telah diselenggarakan dengan baik dan mendapatkan perhatian dari peserta pelatihan. Peserta berantusias membuat sendiri produk permen agaragar buah.

\section{Ucapan Terima Kasih}

Kegiatan PKM ini terselenggara atas pembiayaan dari LPPM Universitas Setia Budi Surakarta sesuai dengan Penugasan Pelaksanaan Program Pengabdian.

\section{Referensi}

Hasriyanti Hasyim, 2015. Karakteristik fisik kimia dan organoleptik permen jelly dari sari buah srikaya pada, Skripsi, Universitas Tadulako, Palu

Wahyuni, Rekna. 2011. Pemanfaatan Kulit Buah Naga Supermerah (Hylocereus costaricensis) sebagai Sumber Antioksidan dan Pewarna Alami pada Pembuatan Jelly. Jurnal Teknologi Pangan Vol.2 No.1. 